\title{
A facile solvent-free synthesis strategy for Co-imbedded zeolite-based Fischer-Tropsch catalysts for direct gasoline production
}

\author{
Mudassar Javed a, ${ }^{a}$, Shilin Cheng a, $\uparrow$, Guihua Zhang a, Cederick Cyril Amoo a, Jingyan Wang c,d,

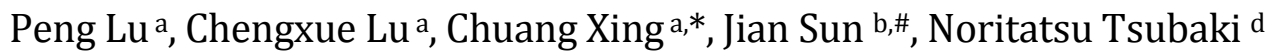 \\ a School of Biological and Chemical Engineering, Zhejiang University of Science and Technology, Hangzhou 310023, Zhejiang, China \\ b Dalian National Laboratory for Clean Energy, Dalian Institute of Chemical Physics, Chinese Academy of Sciences, Dalian 116023, Liaoning, China \\ c Beijing Booming Highchem Technology Co., LTD, Beijing 100005, China \\ d Department of Applied Chemistry, Graduate School of Engineering, University of Toyama, Gofuku 3190, Toyama 9308555, Japan
}

\section{A R T I C L E I N F}

\section{Article history:}

Received 25 August 2019

Accepted 5 October 2019

Published 5 April 2020

\section{Keywords:}

Solvent-free synthesis

Co-imbedded zeolite catalyst

Fischer-Tropsch synthesis

Gasoline

Isoparaffin

\begin{abstract}
A B S T R A C T
A series of Co-imbedded zeolite-based catalysts were synthesized following a facile solvent-free grinding route. The catalytic performance for direct syngas conversion to gasoline range hydrocarbons was compared with their counterpart Co-impregnated zeolite-based catalysts. Successful transformation of solid raw materials to targeted zeolite was confirmed by XRD, SEM, STEM, and $\mathrm{N}_{2}$ physisorption analysis. An in-depth study of acidic strength and acidic site distribution was conducted by $\mathrm{NH}_{3}$-TPD and Py-IR spectroscopy. Acidic strength showed a pivotal role in defining product range. Co@S1, with the weakest acidic strength of silicalite-1 among three types of zeolites, evaded over-cracking of product and exhibited the highest gasoline and isoparaffin selectivity $(\approx 70 \%$ and $30.7 \%$, respectively). Moreover, the solvent-free raw material grinding route for zeolite synthesis accompanies several advantages like the elimination of production of wastewater, high product yield within confined crystallization space, and elimination of safety concerns regarding high pressure due to the absence of the solvent. Facileness and easiness of the solvent-free synthesis route together with promising catalytic performance strongly support its application on the industrial scale.
\end{abstract}

(C) 2020, Dalian Institute of Chemical Physics, Chinese Academy of Sciences. Published by Elsevier B.V. All rights reserved.

\section{Introduction}

Zeolites, with their high thermal stability, ordered open porous structure, high surface area and shape selective properties, have opened numerous opportunities for combining ca- talysis and separation while attracting extensive attention in recent years [1-4]. Normally, zeolites are synthesized using a hydrothermal synthesis route involving a large amount of water as the solvent. The hydrothermal process ends up with safety and environmental issues like the production of polluted

\footnotetext{
* Corresponding author. Tel: +86-571-85070387; Fax: +86-571-85070370; E-mail: xing@zust.edu.cn

\# Corresponding author. Tel/Fax: +86-411-84379283; E-mail: sunj@dicp.ac.cn

†These authors contributed equally to this work.

The authors acknowledge the financial support from the Zhejiang Province Natural Science Foundation (LY19B060001), the Foundation of State Key Laboratory of High-efficiency Utilization of Coal and Green Chemical Engineering (2018-K25), and the Foundation of Zhejiang University of Science and Technology (2019QN18, 2019QN23).

DOI: S1872-2067(19)63436-4 | http://www.sciencedirect.com/science/journal/18722067 | Chin. J. Catal., Vol. 41, No. 4, April 2020
} 
water and dissolution of silica-based species in alkaline media, while the yield of zeolite is also not that high. Moreover, high pressure, required for the process, is difficult to deal with and leads to safety concerns $[2,5]$. Water has been regarded as an essential component in a zeolite synthesis process because of its ability of efficient transportation of reactants during the synthesis. Researchers, in attempt to challenge essentiality of water, introduced dry-gel conversion (DGC) and vapor-phase transport (VPT) routes, where suspended sodium aluminosilicate gel was treated with the mixed vapor of water and amine at a high temperature in a pressurized sealed autoclave. However, in this process, a large amount of water is required for the preparation of gel [6].

In 2012, Xiao et al. [7] introduced a solvent-free silica and aluminosilicate zeolite synthesis route, which involved grinding and subsequent heating of raw materials. Compared with conventional hydrothermal synthesis routes, this solvent-free route exhibits several advantages as follows. (i) High yields: while minimizing raw material losses compared with the hydrothermal process [7]; (ii) space confinement of process: as the process involves only raw materials and no additional solvent [8]; (iii) significant reduction of pollutants and eliminating production of wastewater; (iv) relatively low crystallization pressure due to the absence of liquid solvent which consequently eliminates many safety concerns; (v) high space-time yield process: besides space confinement of the solvent-free process, a high yield can be achieved in remarkably shorter crystallization time as compared with the conventional hydrothermal route at high temperature. (vi) Facile and fast process: in contrast with complications involved in hydrothermal synthesis process, solvent-free zeolite synthesis only involves grinding and crystallization at high temperature, which makes the process extremely facile.

Conversion of syngas $\left(\mathrm{H}_{2}+\mathrm{CO}\right)$, derived from organic waste, coal, natural gas, and biomass, to hydrocarbons has found extensive applications in terms of producing fuels and valuable chemicals $[9,10]$. Researchers have frequently been using zeolite-based active metal catalysts for syngas conversion to hydrocarbons via Fischer-Tropsch synthesis (FTS) [11-13] which led them to define three main types of zeolite-based bifunctional catalysts, known as physical mixture catalysts [14,15], zeolite-supported metallic catalysts [16-19], and core-shell or capsule catalysts [20-23]. Significant progress has been made by several researchers in tuning product selectivity towards gasoline range hydrocarbons $\left(\mathrm{C}_{5}-\mathrm{C}_{11}\right)$ using zeolite-based bifunctional FT catalysts [11]. In a typical process, FT catalysts generally convert syngas to a wide spectrum of hydrocarbons while zeolites promote secondary reactions, like isomerization and hydrocracking $[11,13]$. Acidic sites of zeolites contribute in shifting product towards relatively shorter hydrocarbon chains by hydrocracking of long chains. Specifying acid site distribution in zeolite structure can greatly help to control product range more precisely. Zeolites with strong acid sites shift product to shorter chain hydrocarbons and vice versa. Moreover, confined and open-end channels of zeolites also promote isomerization process.

While conventional petroleum reserves are heading to an end, FTS has come up as a considerable alternative for the production of fuels. Gasoline is one of the most demanded and commonly used fuel in transportation. Literature reports several successful attempts to obtaining high gasoline selectivities over zeolite-supported FT catalysts in direct syngas conversion process $[16,19,24]$. However, core-shell type zeolite catalysts have exhibited more interesting effects in tuning secondary reactions. Tsubaki group [25] greatly enhanced light isoparaffin selectivity by introducing an $\mathrm{HZSM}-5$ layer over $\mathrm{SiO}_{2}$-supported Co core. Dual zeolite shell coated $\mathrm{SiO}_{2}$-supported Fe core, as core-shell catalyst, was employed in direct syngas conversion and significant selectivity for isoparaffin was achieved [26]. A microcapsule catalyst composed of acidic ZSM-5-supported Co core covered with the non-acidic silicalite-1 shell was developed, where silicalite-1 coating contributed in increasing gasoline range hydrocarbons selectivity meanwhile, significantly suppressed $\mathrm{CO}_{2}$ selectivity with its hydrophobic nature [20].

Recently, catalysts based on metal clusters imbedded in zeolite have found extensive applications in FTS [27]. Sun and coworkers [28] used FeAl alloy and entrapped it in HZSM-5 crystals using hydrothermal synthesis. The prepared Raney Fe@HZSM-5 catalyst was employed for direct gasoline production and it exhibited significant outcomes [28]. Imbedment of Co particles inside HZSM-5 crystals was also done by the hydrothermal method where $\mathrm{Co} / \mathrm{SiO}_{2}$ was used as the precursor for zeolite. Synthesized Co@HZSM-5 greatly enhanced gasoline and isoparaffin selectivity for direct syngas conversion [29]. Xing et al. [30] used carbon as hard template to synthesize mesoporous HZSM-5 containing Co clusters entrapped inside the zeolite structure and employed it for direct middle isoparaffins synthesis.

Herein, in this article, we report in-situ crystallization of MFI type zeolites, imbedding Co particles inside the crystal structure via solvent-free strategy. Proposed solvent-free route of zeolite synthesis eliminates safety, product yield, and process complication concerns, as mentioned above. Moreover, synthesized imbedded Co-based catalysts exhibited promising selectivity for gasoline range hydrocarbons. Silicalite- 1 zeolite has unique pore structure and characteristics and optimum acidic sites which can hardly be detected by $\mathrm{NH}_{3}$-TPD at normal conditions and these weak acidic sites are suitable for hydrocracking of longer chain hydrocarbons to gasoline range while preventing over-cracking. The reported route, with its facileness, process safety, and significant performances, can be considered on the commercial scale.

\section{Experimental}

\subsection{Materials}

$\mathrm{Co}\left(\mathrm{NO}_{3}\right)_{2} \cdot 6 \mathrm{H}_{2} \mathrm{O}, \mathrm{NH}_{4} \mathrm{NO}_{3}$, tetrapropylammonium hydroxide (TPAOH, 25 wt $\%$ in water) from Aladdin Industrial Corporation, ethylenediamine (EDA) and $\mathrm{NaOH}$ from Sinopharm Chemical Reagent Co., Ltd., boehmite $\left(\mathrm{Al}_{2} \mathrm{O}_{3}, 70 \mathrm{wt} \%\right)$ from Zibo Senchi Chemical Co., Ltd., and silica (average pore size $=10 \mathrm{~nm}$ ) from Fuji Silysia Chemical Ltd., were used for preparation of all catalysts with no further purification. 


\subsection{Preparation of Co-based silica-supported catalyst}

$\mathrm{Co} / \mathrm{SiO}_{2}$ catalysts with $10 \mathrm{wt} \%$ Co loading was prepared by incipient-wetness impregnation (IWI) of $\mathrm{SiO}_{2}$ support with cobalt nitrate solution [31]. Typically, $2.1 \mathrm{~g}$ of cobalt nitrate was dissolved in $2 \mathrm{~mL}$ of distilled water and the resulting solution was poured dropwise on $5 \mathrm{~g}$ of $\mathrm{SiO}_{2}$ while mixing continuously in ultrasonic environment. The sample was then kept in ultrasonic environment for $30 \mathrm{~min}$ and then in vacuum for $1 \mathrm{~h}$. A subsequent drying at $120{ }^{\circ} \mathrm{C}$ for $6 \mathrm{~h}$ followed by calcination at $400{ }^{\circ} \mathrm{C}$ for $2 \mathrm{~h}$ was performed afterwards to obtain $\mathrm{Co} / \mathrm{SiO}_{2}$ catalyst.

\subsection{Preparation of Co-based zeolite-supported catalyst}

As a typical run, $2.72 \mathrm{~g}$ of $\mathrm{SiO}_{2}$ and $3.25 \mathrm{~g}$ of TPAOH for preparation of silicalite- 1 and $4.89 \mathrm{~g}$ of $\mathrm{SiO}_{2}, 0.55 \mathrm{~g}$ of $\mathrm{NaOH}, 5.2$ $\mathrm{g}$ of EDA and $0.48 \mathrm{~g}$ of boehmite for preparation of NaZSM-5 were grinded for $20 \mathrm{~min}$. Both mixtures were then sealed in Teflon reactors and heated at $200{ }^{\circ} \mathrm{C}$ for $48 \mathrm{~h}$ for silicalite- 1 and $72 \mathrm{~h}$ for NaZSM-5. A subsequent calcination at $550{ }^{\circ} \mathrm{C}$ for $5 \mathrm{~h}$ was performed for both samples resulting in the final product of silicalite- 1 and NaZSM-5. HZSM-5 was prepared with ion exchanging of $1 \mathrm{~g}$ of NaZSM-5 in $20 \mathrm{~mL}$ of $2 \mathrm{~mol} / \mathrm{L}$ aqueous solution of $\mathrm{NH}_{4} \mathrm{NO}_{3}$. Ion exchanging was performed for $4 \mathrm{~h}$ at $90{ }^{\circ} \mathrm{C}$ and product was then filtered and dried at $400{ }^{\circ} \mathrm{C}$ for $2 \mathrm{~h}$.

Three kinds of prepared zeolites were then loaded with 10 $w t \%$ Co following incipient-wetness impregnation (IWI) method and prepared catalysts were tagged as Co/S1, Co/NaZSM-5 and Co/HZSM-5 on basis of respective zeolite support.

\subsection{Preparation of Co-imbedded zeolite-based catalyst}

As a typical run, $2.72 \mathrm{~g}$ of $10 \mathrm{wt} \% \mathrm{Co} / \mathrm{SiO}_{2}$ and $3.25 \mathrm{~g}$ of TPAOH for preparation of Co@S1 and $4.89 \mathrm{~g}$ of $10 \mathrm{wt} \%$ $\mathrm{Co} / \mathrm{SiO}_{2}, 0.55 \mathrm{~g}$ of $\mathrm{NaOH}, 5.2 \mathrm{~g}$ of EDA and $0.48 \mathrm{~g}$ of boehmite for preparation of Co@NaZSM-5 were grinded for $20 \mathrm{~min}$. Both mixtures were then sealed in Teflon reactors and heated at 200 oC for 48 h for Co@S1 and 72 h for Co@NaZSM-5. A subsequent calcination at $550{ }^{\circ} \mathrm{C}$ for $5 \mathrm{~h}$ was performed for both samples resulting in the final product of Co@S1 and Co@NaZSM-5. Co@HZSM-5 was prepared with ion exchanging of $1 \mathrm{~g}$ of Co@NaZSM-5 in $20 \mathrm{~mL}$ of $2 \mathrm{~mol} / \mathrm{L}$ aqueous solution of $\mathrm{NH}_{4} \mathrm{NO}_{3}$ as per above mentioned procedure.

\subsection{Characterization}

X-ray powder diffraction (XRD) patterns were determined with a Rigaku Ultima IV diffractometer using $\mathrm{Cu} \mathrm{K}_{\alpha}$ radiation source $(\lambda=1.54 \AA)$, scanning rate of $2 \% / \mathrm{min}$ in the range of $5^{\circ}-50^{\circ}$ at $40 \mathrm{kV}$ and $20 \mathrm{~mA}$. The nitrogen adsorption and desorption experiments of the samples were performed on an automatic gas adsorption system (Autosorb-iQ, Quantachrome). Temperature-programmed desorption ( $\mathrm{NH}_{3}$-TPD) was carried out on a BELCAT-B3 apparatus (BEL Co.) equipped with a thermal conductivity detector (TCD). The surface morphology of all samples was employed by using a JEOL JSM6360LV scanning electron microscope (SEM). Scanning transmission electron microscopy (STEM) images were performed on the sample with a FEI Tecnai F20 operating at $200 \mathrm{kV}$. The IR spectra of pyridine adsorbed on the sample were measure with an FTIR-650 FT-IR spectrometer. The thin wafer sample was pre-treated at $450{ }^{\circ} \mathrm{C}$ in vacuum. With subsequent cooling to room temperature, the sample was exposed to pyridine at room temperature for $5 \mathrm{~min}$ and evacuated at $150{ }^{\circ} \mathrm{C}$ for $30 \mathrm{~min}$. IR spectra were measured at room temperature.

\subsection{Catalytic performance test}

Catalytic activity testing for Co-based catalysts applied in FTS for direct synthesize of gasoline range hydrocarbons was carried out for $6 \mathrm{~h}$ in a fixed-bed reactor at reaction conditions of $260{ }^{\circ} \mathrm{C}, 1.0 \mathrm{MPa}, \mathrm{H}_{2} / \mathrm{CO}=2 / 1$ and $\mathrm{W} / \mathrm{F}=6 \mathrm{~g} \mathrm{~h} / \mathrm{mol}$. The catalyst weight of $0.3 \mathrm{~g}$, for each catalyst, together with quartz of 0.5 $\mathrm{g}$ was fixed in continuous flow stainless-steel reactor with an inner diameter of $6.8 \mathrm{~mm}$. Prior to reaction, the as-prepared catalysts were in-situ reduced at $400{ }^{\circ} \mathrm{C}$ for $4 \mathrm{~h}$ in pure $\mathrm{H}_{2}$ flow (40 $\mathrm{mL} / \mathrm{min})$. The gaseous products after reaction were detected by two online gas chromatographs (GC-TCD, GC-FID) with TDX-01 and aluminium oxide columns, respectively. The heavy hydrocarbons, captured by an ice trap placed between reactor and back pressure regulator, were analysed using an offline gas chromatograph (Shimadzu GC-2014, FID, RTx-5).

\section{Results and discussion}

Fig. 1 represents XRD patterns for all prepared Co-based catalysts after calcination. All samples, except $\mathrm{Co} / \mathrm{SiO}_{2}$, exhibit a clear MFI topology XRD pattern at $2 \theta=7^{\circ}-30^{\circ}$, which confirms

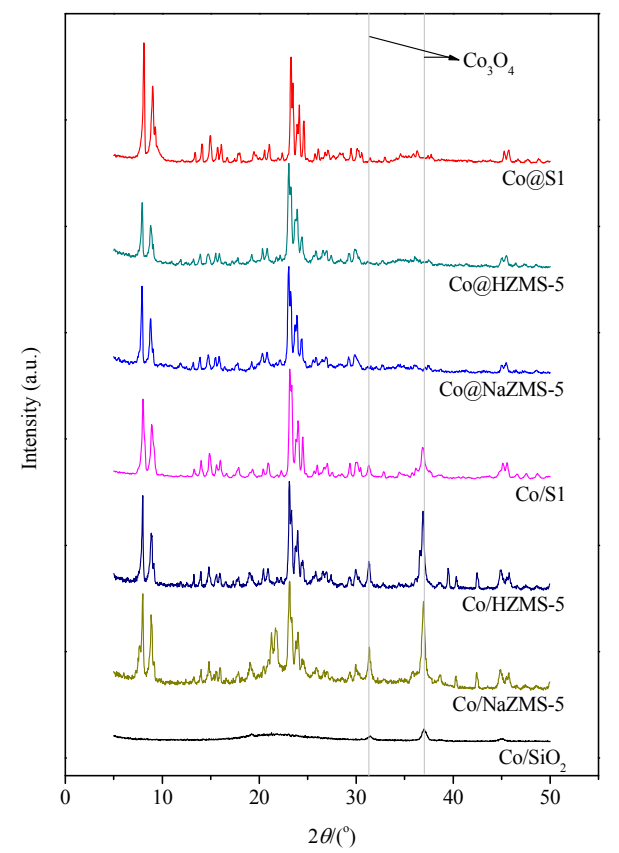

Fig. 1. XRD patterns for all Co-based calcined catalysts. 


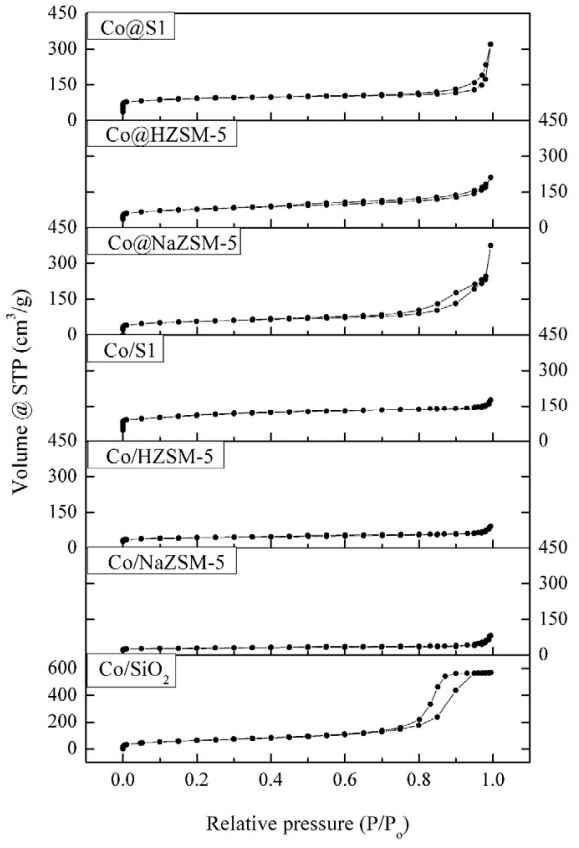

Fig. 2. $\mathrm{N}_{2}$ sorption isotherm for synthesized Co-based catalysts.

the success of solvent-free synthesis of ZSM-5 and silicalite-1 zeolites. $\mathrm{Co}_{3} \mathrm{O}_{4}$ phases are also detected at $2 \theta=31.3^{\circ}$ and $36.8^{\circ}$. For all zeolite-supported Co-based catalysts, Co/NaZSM-5, $\mathrm{Co} / \mathrm{HZSM}-5$, and $\mathrm{Co} / \mathrm{S} 1, \mathrm{Co}_{3} \mathrm{O}_{4}$ phase intensities are relatively high because of easy accessibility of Co oxides dispersed over zeolite surface by the IWI method. However, in the case of Co@zeolite catalysts, $\mathrm{Co}_{3} \mathrm{O}_{4}$ phases are barely detectable, which is due to the entrapment of Co particles inside the zeolite structure.

A detailed study of micro- and mesoporous framework features for all catalysts was conducted by $\mathrm{N}_{2}$ physisorption, and the results are presented in Fig. 2 and Table 1. Generally, Fig. 2 shows a sheer uptake of $\mathrm{N}_{2}$ molecules at low relative pressure, which is then observed to be following relatively horizontal adsorption and desorption branches and a second intake at high relative pressure. A wide distribution of mesopores is confirmed with a broad hysteresis loop of adsorption and desorption curves for $\mathrm{Co} / \mathrm{SiO}_{2}$. Whereas, for all zeolite-based cat-

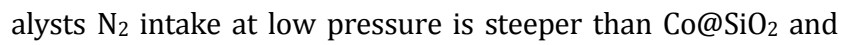

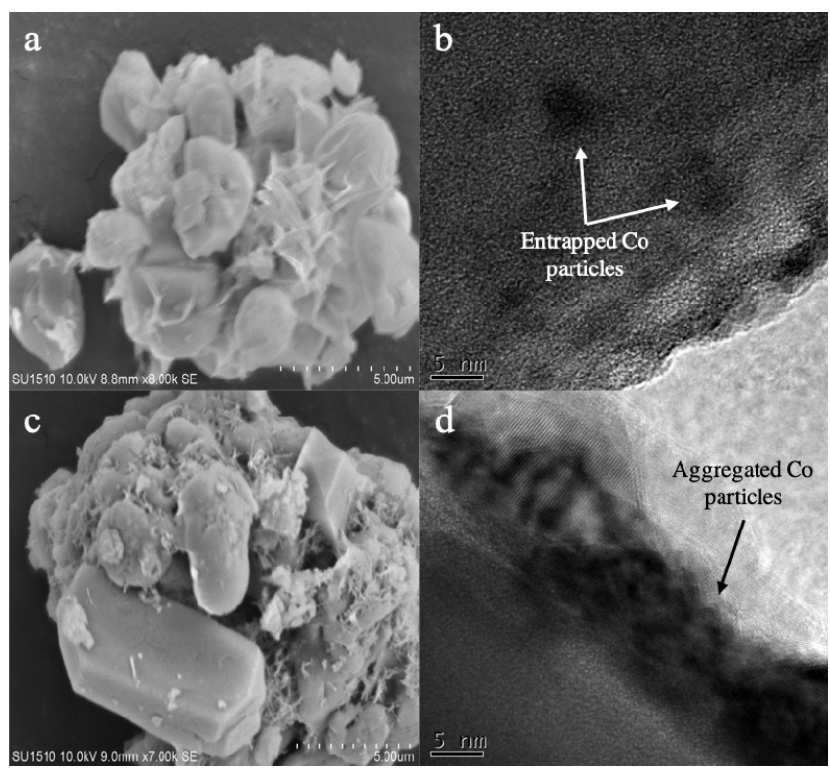

Fig. 3. SEM and HRTEM images of Co@S1 (a, b) and Co/NaZSM-5 (c, d).

adsorption and desorption curves are closer to each other which suggests a significant decrease in mesopore intensity and formation of micropores in structure. This confirms that suggested solvent-free grinding route has efficiently transformed raw mesoporous silica to microporous dominant structure. This is also evident from a decrease in mesopore and increase in micropore areas and volumes after solvent-free zeolite synthesis process, compared with parent silica source (Table 1). Furthermore, isotherms of cobalt-imbedded zeolite-based catalysts, Co@NaZSM-5, Co@HZSM-5, and Co@S1, show hysteresis loop, which suggests the presence of mesopores in the structure which plays a pivotal role in the mass transfer of reactants and products. However, for cobalt-impregnated zeolite-based catalysts, Co/NaZSM-5, Co/HZSM-5, and Co/S1, hysteresis loop seems to be nearly disappeared, which is due to the partial covering of pore openings with cobalt particles. Table 1 also confirms it, as mesopore volume for all three Co-impregnated catalysts is significantly lower than mesopore volume of Co-imbedded zeolite-based catalysts. In general, both impregnated and imbedded silicalite-1-based catalysts, Co/S1 and Co@S1, exhibit higher micropore volume, surface area, and total surface area, suggesting

Table 1

Surface area and porosity of synthesized catalysts.

\begin{tabular}{|c|c|c|c|c|c|c|}
\hline \multirow{2}{*}{ Catalyst } & \multicolumn{3}{|c|}{$S^{\mathrm{a}}\left(\mathrm{m}^{2} / \mathrm{g}\right)$} & \multicolumn{3}{|c|}{$V\left(\mathrm{~cm}^{3} / \mathrm{g}\right)$} \\
\hline & Total & Micropore ${ }^{b}$ & Mesopore & Total c & Micropore ${ }^{b}$ & Mesopore \\
\hline $\mathrm{Co} / \mathrm{SiO}_{2}$ & 223 & 11 & 213 & 0.88 & 0.00 & 0.88 \\
\hline Co/S1 & 351 & 236 & 115 & 0.27 & 0.12 & 0.15 \\
\hline Co/NaZSM-5 & 101 & 74 & 27 & 0.13 & 0.03 & 0.09 \\
\hline Co/HZSM-5 & 138 & 97 & 41 & 0.14 & 0.05 & 0.09 \\
\hline Co@S1 & 293 & 232 & 61 & 0.49 & 0.12 & 0.38 \\
\hline Co@NaZSM-5 & 187 & 98 & 88 & 0.58 & 0.05 & 0.53 \\
\hline Co@HZSM-5 & 254 & 135 & 118 & 0.33 & 0.07 & 0.26 \\
\hline
\end{tabular}

\section{aBT surface area.}

b Microporous surface area and pore volume evaluated by $t$-plot method.

c Total pore volume calculated by BJH method at $P / P_{0} \geq 0.99$. 

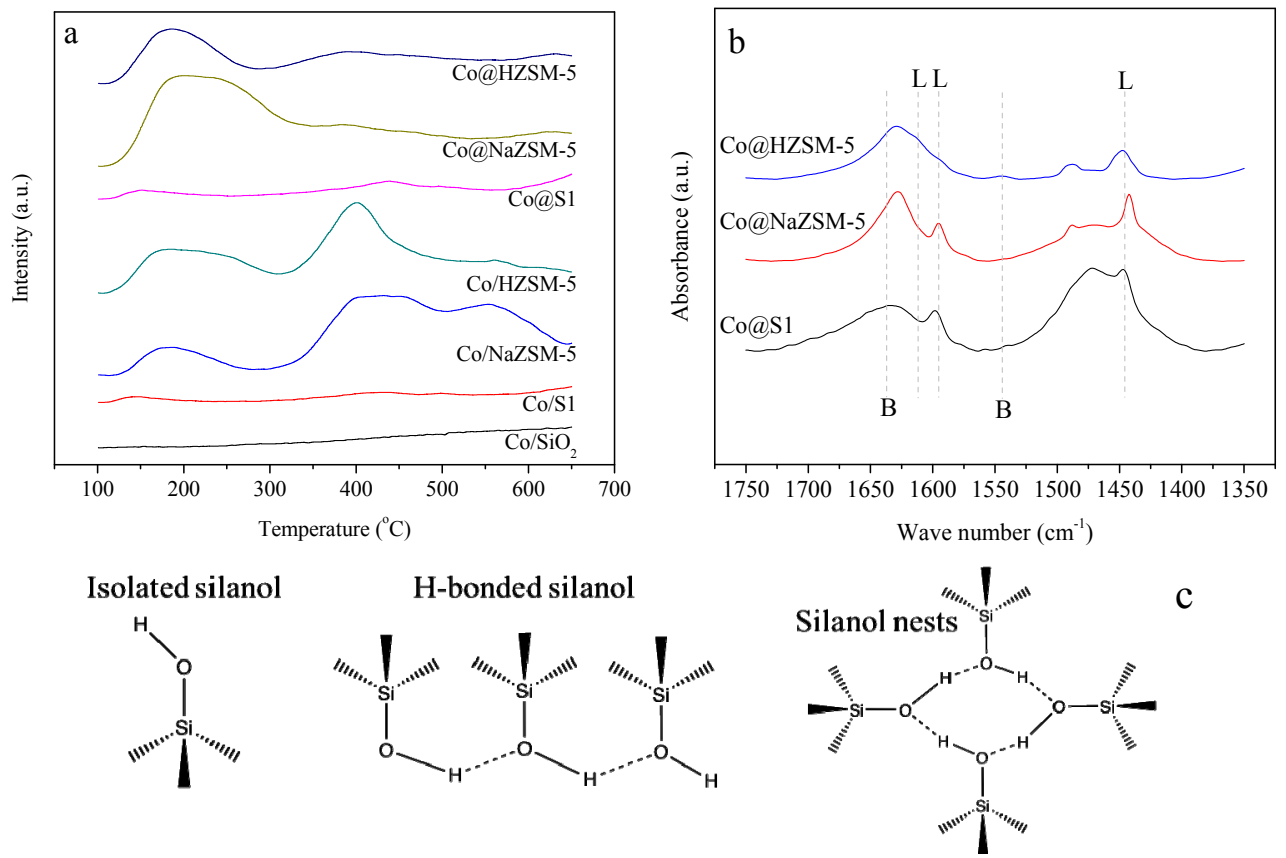

Fig. 4. $\mathrm{NH}_{3}$-TPD profiles (a), FTIR spectra of Py adsorbed and subsequent outgassing at $150{ }^{\circ} \mathrm{C}$ (b), and depiction of three types of silanols (c), for prepared metal-impregnated and metal-imbedded zeolites.

the most open porous structure with high porosity.

Crystal morphology and infrastructure were investigated with SEM and STEM analysis and images for Co@S1 and Co/NaZSM-5 are presented in Fig. 3. SEM images in Fig. 3a and $3 c$ exhibit a nearly regular crystal shape with representative MFI observations. Solvent-free synthesized Co@S1 shows relatively smaller size crystals than Co/NaZSM-5. Whereas, relatively larger crystal size for NaZSM-5 is believed to be associated with high alkalinity of mixture during crystallization. HRTEM image of Co@S1, Fig. 3b, displays Co particles entrapped inside the body of zeolite crystal while in case of catalysts prepared by wetness impregnation (Co/NaZMS-5, Fig 3d), a layer of Co particles aggregated across the surface of zeolite support is observed.

Acidic sites in zeolite are mainly responsible for defining product range with hydrocracking. A detailed investigation of acidic sites present across crystal structure was done by performing $\mathrm{NH}_{3}$-TPD and Py-IR spectroscopy, and the results are presented in Fig. 4 and Table 2. Fig. 4a presents two obvious $\mathrm{NH}_{3}$ adsorption peaks for most of the samples. The peak at $100-300{ }^{\circ} \mathrm{C}$ is ascribed to weak and at $300-500{ }^{\circ} \mathrm{C}$ attributed to strong acidic sites. Among all, HZSM-5, for both Co/HZSM-5 and Co@HZSM-5, exhibit higher intensities for strong acidic sites, indicating stronger capabilities of hydrocracking. These strong acidic sites in HZSM-5 are Brönsted acid sites formed due to the presence of $\mathrm{H}^{+}$(proton) in the zeolite framework. Generally, NaZSM-5-based catalysts, Co/NaZSM-5 and Co@NaZSM-5, show higher intensities for weak acid sites than strong acid sites, suggesting an overall lower acidity than HZSM-5-based catalysts. For Co/S1 and Co@S1, very small adsorption peaks are observed. Silicalite-1 has slight acidic characteristics, which are hardly detected by $\mathrm{NH}_{3}$-TPD at normal conditions. Py-IR spectroscopy was performed to examine acidic sites distribu- tion of silicalite-1-based catalyst. Fig 4b presents Py-IR spectra for the three Co-imbedded zeolite-based catalysts, Co@S1, Co@NaZSM-5, and Co@HZSM-5. IR bands at 1445, 1595, and $1612 \mathrm{~cm}^{-1}$ are ascribed to the adsorption of pyridine coordinated on Lewis acid sites related to the unsaturated $\mathrm{Al}$ species and internal defects [32,33]. IR bands near 1545 and $1637 \mathrm{~cm}^{-1}$ are associated with pyridine adsorption occurring on Brönsted acid sites, which are generally stem from the tetrahedral framework $\mathrm{Al}$ atoms [34]. Fig $4 \mathrm{~b}$ and Table 2 show that all three zeolite-based catalysts, Co@S1, Co@NaZSM-5, and Co@HZSM-5, exhibit Lewis and Brönsted acid sites, whereas among all three, Co@HZSM-5 shows the highest number of Brönsted acid (0.01926 mmol/g) and total acid sites (0.19707 mmol/g) as well. Py-IR spectroscopy of Co@S1 also confirms that with its Al-free framework, Co@S1 displays minimum total acid sites $(0.04511 \mathrm{mmol} / \mathrm{g})$, indicating its weak acidic characteristics, which is in good agreement with $\mathrm{NH}_{3}-\mathrm{TPD}$ analysis. Fig. 4c presents three types of hydroxyl species in MFI (ZSM-5 and silicalite-1) structure, which are isolated silanol groups, hydrogen-bonded hydroxyl and bridging hydroxyl groups [35]. The acidity of isolated silanol is considered to be too weak to take part in hydrocracking of hydrocarbons and, since silicalite- 1 has Al-free framework, the hydrogen-bonded silanol groups in silicalite-1 framework are responsible for weak

Table 2

Acidity of Co-imbedded zeolite-based catalysts ${ }^{\text {a }}$.

\begin{tabular}{lccc}
\hline Catalyst & $\mathrm{B}(\mathrm{mmol} / \mathrm{g})$ & $\mathrm{L}(\mathrm{mmol} / \mathrm{g})$ & Total $(\mathrm{mmol} / \mathrm{g})$ \\
\hline Co@S1 & 0.00626 & 0.03885 & 0.04511 \\
Co@NaZSM-5 & 0 & 0.13521 & 0.13521 \\
Co@HZSM-5 & 0.01926 & 0.17781 & 0.19707 \\
\hline
\end{tabular}

a Acidity was calculated by Py-IR spectroscopy. B = Brönsted acidity, L = Lewis acidity. 
Table 3

Catalytic activity and product selectivity over the synthesized Co-based catalysts.

\begin{tabular}{lcrrrrr}
\hline \multirow{2}{*}{ Catalyst } & CO & \multicolumn{5}{c}{ Selectivity (\%) } \\
\cline { 3 - 7 } & Conversion (\%) & $\mathrm{CO}_{2}$ & $\mathrm{CH}_{4}$ & $\mathrm{C}_{2-4}$ & $\mathrm{C}_{5-11}$ & $\mathrm{C}_{12+}$ \\
\hline $\mathrm{Co} / \mathrm{SiO}_{2}$ & 31.0 & 7.2 & 14.3 & 33.6 & 44.3 & 7.8 \\
Co/S1 & 45.8 & 7.7 & 16.2 & 22.7 & 47.1 & 14.0 \\
Co/NaZSM5 & 33.9 & 35.7 & 11.6 & 27.0 & 57.4 & 4.0 \\
Co/HZSM5 & 39.7 & 9.0 & 19.3 & 29.2 & 45.6 & 5.9 \\
Co@S1 & 28.3 & 8.2 & 8.3 & 18.5 & 68.8 & 4.4 \\
Co@NaZSM-5 & 18.6 & 9.6 & 11.5 & 21.9 & 62.7 & 3.9 \\
Co@HZSM-5 & 30.9 & 10.2 & 13.9 & 31.3 & 53.0 & 1.8 \\
\hline
\end{tabular}

Reaction conditions: $T=260^{\circ} \mathrm{C}, P=1.0 \mathrm{MPa}, \mathrm{H}_{2} / \mathrm{CO}=2 / 1, \mathrm{~W} / \mathrm{F}=6 \mathrm{~g} \mathrm{~h}$ $\mathrm{mol}^{-1}$.

Brönsted acid sites, which can practically contribute in hydrocracking [36-38].

Table 3 compares the catalytic performance and product selectivity of all Co-based catalysts for direct syngas conversion to gasoline. Generally, supported Co-based catalysts $\left(\mathrm{Co} / \mathrm{SiO}_{2}\right.$, $\mathrm{Co} / \mathrm{S} 1$, Co/NaZSM-5, and Co/HZSM-5) prepared by the wetness impregnation method exhibited higher CO conversion than their respective Co imbedded in zeolite forms (Co@S1, Co@NaZSM-5, and Co@HZSM-5). This is mainly due to the uniform distribution and easy access of Co active sites dispersed over catalyst surface. In the case of Co-imbedded zeolite-based catalysts, Co particles are entrapped inside zeolite channels and structure and comparatively less exposed to syngas, which decreased the CO conversion.

During syngas conversion over supported metal-based catalysts, product distribution is mainly defined by the acidic strength and acid site intensity of the support. Herein, $\mathrm{NH}_{3}$-TPD and Py-IR analysis suggest acidic strength of zeolite supports to fall in an order of HZSM-5>NaZSM-5>S1. High intensity of strong acid sites with excessive active sites for hydrocracking shifts overall product to relatively shorter chain hydrocarbons, whereas weakly acidic or non-acidic support tends to produce longer chain products. For both groups of catalysts, Co-impregnated and Co-imbedded zeolite-based, silicalite-1-based catalysts showed higher selectivity towards longer chain hydrocarbons with $\mathrm{C}_{12}$ - selectivity of $14.0 \%$ for Co/S1 and 4.5\% for Co@S1 due to the weakest acidity among all zeolite-supported catalysts. In contrast with silicalite-1, NaZSM-5 and HZSM-5 based catalysts exhibited relatively lower selectivity for long chain hydrocarbons with a minimum of $1.8 \% \mathrm{C}_{12+}$ selectivity over Co@HZSM-5. This is because of comparatively strong acidity, which led to over-cracking and increased shorter chain hydrocarbon content in the final product. Among all catalysts, Co@S1 seems to have the most optimum acidic strength for cracking of longer chains into the gasoline $\left(\mathrm{C}_{5}-\mathrm{C}_{11}\right)$ range hydrocarbons, which lead to the highest gasoline selectivity $(\approx 70 \%)$. Slight acidic nature of silicalite-1 turned out to be more suitable for cracking of hydrocarbons in gasoline range than strong acidic characteristics of NaZSM-5 and HZSM-5, which, especially in the case of Co@HZSM-5, over-cracked long chain hydrocarbons and increased selectivity for lower hydrocarbons. Moreover, Co@S1 with a relatively open porous structure and high pore volume promotes structure rearrangement of the product upon passing through channels, which increased isoparaffin content in the final product and showed maximum isoparaffin selectivity (30.7\%) among all catalysts (Fig. 5). Compared with other catalysts, a significant reduction in $\mathrm{CH}_{4}$ selectivity (8.3\%) was also observed for Co@S1, which is also ascribed with weak acidic characteristics of silicalite- 1 .

In FTS, production of $\mathrm{CO}_{2}$ is attributed to the WGS reaction occurring under FT reaction conditions. Silanol group ( $\mathrm{Si}-\mathrm{OH})$ is the most active site for WGS reaction in zeolites. Hence, zeolite-based catalysts are observed to exhibit a slight increase in $\mathrm{CO}_{2}$ selectivity by promoting WGS reaction the presence of silanol group. In the case of Co/NaZSM-5, the dramatically high $\mathrm{CO}_{2}$ selectivity is believed to be derived from the presence of $\mathrm{Na}$ ions in the catalyst. Literature reports that alkali ( $\mathrm{Na}$ ) promotes the WGS reaction by weakening the formate $(\mathrm{C}-\mathrm{H})$ bond significantly [39]. However, unlike Co/NaZSM-5, Co@NaZSM-5 does not show that high $\mathrm{CO}_{2}$ selectivity. It is believed that for Co/NaZSM-5, Na ions abundantly exist close to the metal sites across the surface of the zeolite, which increases the probability of interaction of $\mathrm{CO}$ molecules with water molecules produced over the neighbouring metal sites during the formation of hydrocarbons. While in the case of Co@NaZSM-5, the metal sites are dispersed inside the crystal of zeolite and the primary reaction of hydrogenation mostly occurs inside the channels of zeolite, where Na ions are not as closely spaced with metal sites as in the case of Co/NaZSM-5. Hence, the probability of interaction of CO molecule with the formed water molecules is relatively low.

In summary, among the three types of solvent-free synthe-

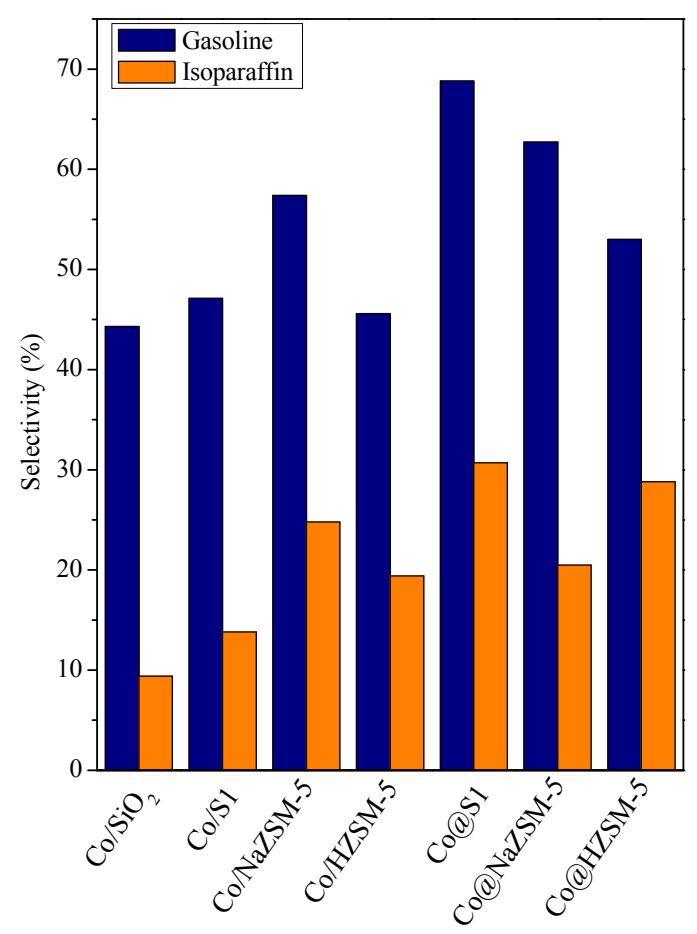

Fig. 5. Gasoline and isoparaffin selectivity achieved over synthesized catalysts. 
sized zeolite supports (HZSM-5, NaZSM-5, and silicalite-1), silicalite-1, in Co-imbedded zeolite-based catalyst (Co@S1), exhibited the least acidity, which had generally proved favourable for high gasoline selectivity $(\approx 70 \%)$ with an overall high isoparaffin content (30.7\%) in end-product and a suppressed $\mathrm{CH}_{4}$ and $\mathrm{CO}_{2}$ selectivity $8.3 \%$ and $8.2 \%$, respectively. This report suggests that besides unique benefits of environmental safety, facile and simple synthesis process and high product yield within confined crystallisation space, solvent-free synthesis of zeolite can successfully be employed to synthesize metal@zeolite catalysts, which exhibit very promising performance for direct syngas conversion via FTS.

\section{Conclusions}

In recent years, metal-imbedded zeolites with hierarchical porous structure have found extensive applications in the field of $\mathrm{C}_{1}$ chemistry. A series of Co-imbedded zeolite was prepared and catalytic performance was compared with its analogous series of Co-based zeolite-supported catalysts for direct conversion of syngas to gasoline range hydrocarbons via FTS. Solvent-free raw material grinding, followed by crystallization at an elevated temperature in an autoclave, was adapted for the preparation of Co-based zeolite-supported (Co/S1, Co/NaZSM-5, and Co/HZSM-5) and Co-imbedded in zeolite (Co@S1, Co@NaZMS-5, Co@HZSM-5) catalysts. The typical synthesis route accompanies unique advantages distinguished among other zeolite synthesis techniques. Co-based catalysts, synthesized by solvent-free raw material grinding route, exhibited promising catalytic performance and significantly high gasoline selectivity. The product range was greatly affected by the acidic strength of zeolite. Among three kinds of zeolites (silicalte-1, NaZSM-5, and HZSM-5), silicalite-1 tends to show the weakest acidic characteristics. Slight acidic behaviour of silicalite-1 proved to be more favourable for cracking of long chains to gasoline range hydrocarbons, whereas HZSM-5 with strong Brönsted acid sites promoted over-cracking and shifted product to lower hydrocarbons. Co@S1, with optimum acidic strength and open porous structure, showed maximum gasoline selectivity $(\approx 70 \%)$ while significantly suppressing $\mathrm{CH}_{4}$ and $\mathrm{CO}_{2}$ selectivity to $8.3 \%$ and $8.2 \%$, respectively. The highest selectivity $(30.7 \%)$ of overall isoparrafin content was also observed for Co@S1 among all catalysts. Weak acid sites across catalyst surface and inside channels and high mass flow through open porous structure greatly contributed to increasing isoparaffin content in the final product. Moreover, hydrophobic nature and absence of strong Brönsted acid sites in silicalite- 1 reduced kinetics for WGS reaction, which ultimately led to a suppressed $\mathrm{CO}_{2}$ selectivity. Conclusively, this article reports a successful solvent-free synthesis route for MFI type zeolites and accounts an in-depth insight of the effect of acidic strength of zeolite in defining product range. The suggested synthesis route for metal-imbedded zeolite accompanies several advantages and is a promising and facile approach for in-

\section{Graphical Abstract}

Chin. J. Catal., 2020, 41: 604-612 doi: S1872-2067(19)63436-4

A facile solvent-free synthesis strategy for Co-imbedded zeolite-based Fischer-Tropsch catalysts for direct gasoline production

Mudassar Javed, Shilin Cheng, Guihua Zhang, Cederick Cyril Amoo, Jingyan Wang, Peng Lu, Chengxue Lu, Chuang Xing*, Jian Sun *, Noritatsu Tsubaki

Zhejiang University of Science and Technology, China; Dalian Institute of Chemical Physics, Chinese Academy of Sciences, China;

Beijing Booming Highchem Technology Co., LTD, China; University of Toyama, Japan
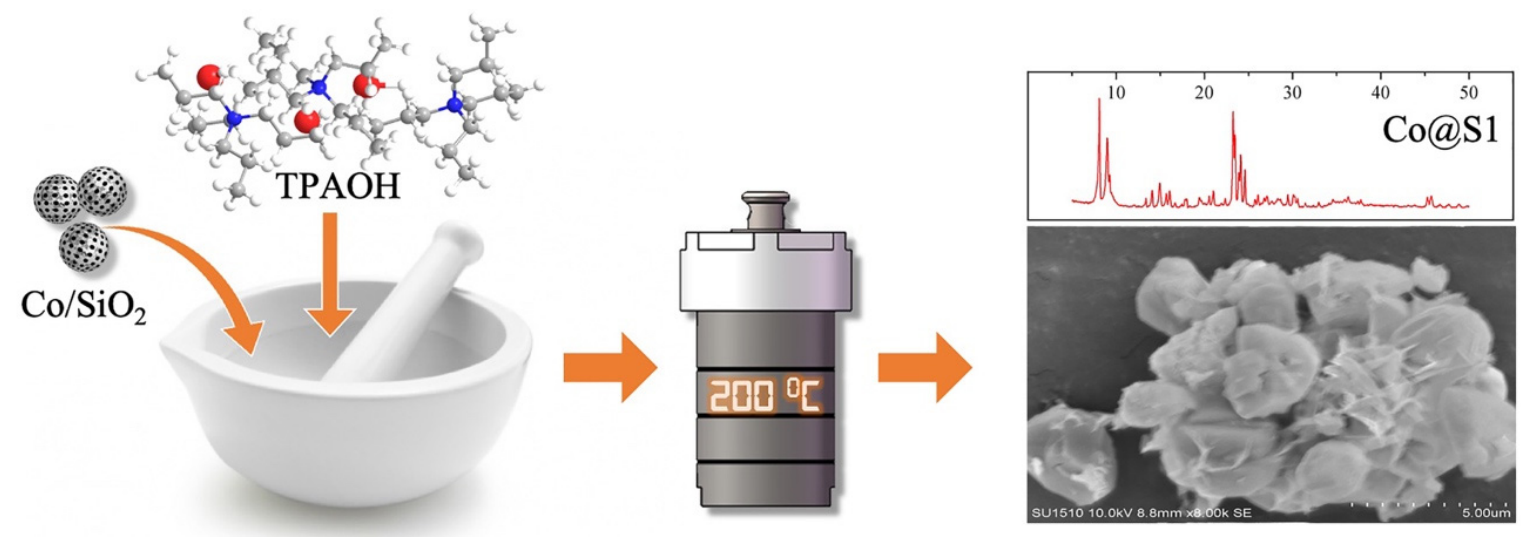

A facile and green solvent-free solid raw material grinding route was used to prepare Co-imbedded zeolite-based catalysts for direct gasoline production from syngas via Fischer-Tropsch synthesis. 
dustrial metal-zeolite-based catalysis.

\section{Acknowledgments}

The authors acknowledge the financial support from the Zhejiang Province Natural Science Foundation (LY19B060001), the Foundation of State Key Laboratory of High-efficiency Utilization of Coal and Green Chemical Engineering (2018-K25), and the Foundation of Zhejiang University of Science and Technology (2019QN18, 2019QN23).

\section{References}

[1] S. Sartipi, M. Makkee, F. Kapteijn, J. Gascon, Catal. Sci. Technol,, 2014, 4, 893-907.

[2] X. Meng, F. S. Xiao, Chem. Rev., 2014, 114, 1522-1544.

[3] N. Li, F. Jiao, X. Pan, Y. Chen, J. Feng, G. Li, X. Bao, Angew. Chem. Int. Ed., 2019, 58, 7400-7404.

[4] Y. Wang, J. Energy Chem., 2016, 25, 169-170.

[5] C. S. Cundy, P. A. Cox, Chem. Rev., 2003, 103, 663-702.

[6] W. Xu, J. Dong, J. Li, J. Li, F. Wu, J. Chem. Soc., Chem. Commun., 1990, $10,755-756$.

[7] L. Ren, Q. Wu, C. Yang, L. Zhu, C. Li, P. Zhang, H. Zhang, X. Meng, F. S. Xiao, J. Am. Chem. Soc., 2012, 134, 15173-15176.

[8] Q. Wu, X. Wang, G. Qi, Q. Guo, S. Pan, X. Meng, J. Xu, F. Deng, F. T. Fan, Z. Feng, J. Am. Chem. Soc., 2014, 136, 4019-4025.

[9] M. Ding, Y. Yang, B. Wu, Y. Li, T. Wang, L. Ma, Appl. Energy, 2015, 160, 982-989.

[10] F. Yu, T. Lin, X. Wang, S. Li, Y. Lu, H. Wang, L. Zhong, Y. Sun, Appl. Catal. A Gen., 2018, 563, 146-153.

[11] Q. H. Zhang, J. C. Kang, Y. Wang, ChemCatChem, 2010, 2, 1030-1058.

[12] M. E. Dry, Catal. Today, 2002, 71, 227-241.

[13] Q. H. Zhang, W. P. Deng, Y. Wang, J. Energy Chem., 2013, 22, 27-38.

[14] Y. Xu, D. Liu, X. Liu, Appl. Catal. A Gen., 2018, 552, 168-183.

[15] J. Wei, Q. Ge, R. Yao, Z. Wen, C. Fang, L. Guo, H. Xu, J. Sun, Nat. Commun., 2017, 8, 15174.

[16] C. Xing, J. Sun, G. Yang, W. Shen, L. Tan, P. Zhu, Q. Wei, J. Li, M. Kyodo, R. Yang, Y. Yoneyama, N. Tsubaki, Fuel Process. Technol., 2015, 136, 68-72.

[17] Q. H. Lin, G. H. Yang, Q. J. Chen, R. G. Fan, Y. Yoneyama, H. L. Wan, N. Tsubaki, ChemCatChem, 2015, 7, 682-689.

[18] Y. Li, T. Wang, C. Wu, Y. Lv, N. Tsubaki, Energy Fuels, 2008, 22,
1897-1901.

[19] P. Lu, J. Sun, P. F. Zhu, T. Abe, R. Q. Yang, A. Taguchi, T. Vitidsant, N. Tsubaki, J. Energy Chem., 2015, 24, 637-641.

[20] M. Javed, S. Cheng, G. Zhang, P. Dai, Y. Cao, C. Lu, R. Yang, C. Xing, S. Shan, Fuel, 2018, 215, 226-231.

[21] C. Xing, J. Sun, Q. Chen, G. Yang, N. Muranaka, P. Lu, W. Shen, P. Zhu, Q. Wei, J. Li, J. Mao, R. Yang, N. Tsubaki, Catal. Today, 2015, 251, 41-46.

[22] M. Javed, G. Zhang, W. Gao, Y. Cao, P. Dai, X. Ji, C. Lu, R. Yang, C. Xing, J. Sun, Catal. Today, 2019, 330, 39-45.

[23] G. Yang, J. He, Y. Zhang, Y. Yoneyama, Y. Tan, Y. Han, T. Vitidsant, N. Tsubaki, Energy Fuels, 2008, 22, 1463-1468.

[24] J. Sun, W. Niu, A. Taguchi, T. Abe, Y. Yoneyama, N. Tsubaki, Catal. Sci. Technol., 2014, 4, 1260-1267.

[25] G. Yang, C. Xing, W. Hirohama, Y. Jin, C. Zeng, Y. Suehiro, T. Wang, Y. Yoneyama, N. Tsubaki, Catal. Today, 2013, 215, 29-35.

[26] Y. Jin, G. Yang, Q. Chen, W. Niu, P. Lu, Y. Yoneyama, N. Tsubaki, J. Memb. Sci., 2015, 475, 22-29.

[27] L. Wang, S. Xu, S. He, F.-S. Xiao, Nano Today, 2018, 20, 74-83.

[28] B. Sun, G. Yu, J. Lin, K. Xu, Y. Pei, S. Yan, M. Qiao, K. Fan, X. Zhang, B. Zong, Catal. Sci. Technol., 2012, 2, 1625-1629.

[29] J. Y. Liu, J. F. Chen, Y. Zhang, Catal. Sci. Technol., 2013, 3, 2559-2564.

[30] C. Xing, W. Shen, G. Yang, R. Yang, P. Lu, J. Sun, Y. Yoneyama, N. Tsubaki, Catal. Commun., 2014, 55, 53-56.

[31] T.J. Wang, S.B. Qiu, Y.J. Weng, L.G. Chen, Q.Y. Liu, J.X. Long, J. Tan, Q. Zhang, Q. Zhang, L.L. Ma, Appl. Energy, 2015, 160, 329-335.

[32] M. J. Climent, A. Corma, S. Iborra, S. Miquel, J. Primo, F. Rey, J. Catal., 1999, 183, 76-82.

[33] G. L. Zhao, J. W. Teng, Z. Xie, Y. Tang, W. M. Yang, Q. L. Chen, Chin. J. Catal., 2005, 26, 1083-1087

[34] X. Zhang, J. Zhong, J. Wang, L. Zhang, J. Gao, A. Liu, Fuel Process. Technol., 2009, 90, 863-870.

[35] K. Barbera, F. Bonino, S. Bordiga, T. V. W. Janssens, P. Beato, J. Catal., 2011, 280, 196-205.

[36] A. A. Gabrienko, I. G. Danilova, S. S. Arzumanov, A. V. Toktarev, D. Freude, A. G. Stepanov, Microporous Mesoporous Mater, 2010, 131, 210-216.

[37] X. Meng, Q. Yu, Y. Gao, Q. Zhang, C. Li, Q. Cui, Catal. Commun., 2015, 61, 67-71.

[38] B. Bonelli, L. Forni, A. Aloise, J. B. Nagy, G. Fornasari, E. Garrone, A. Gedeon, G. Giordano, F. Trifirò, Microporous Mesoporous Mater., 2007, 101, 153-160.

[39] H. N. Evin, G. Jacobs, J. Ruiz-Martinez, U.M. Graham, A. Dozier, G. Thomas, B. H. Davis, Catal. Lett., 2008, 122, 9-19.

\title{
无溶剂路线制备分子篮封装的钴基催化剂及其在费托合成制汽油反应中的应用
}

\author{
Mudassar Javed ${ }^{\mathrm{a}, \dagger}$ ，程世林 ${ }^{\mathrm{a}, \dagger}$ ，张桂华 ${ }^{\mathrm{a}}$, Cederick Cyril Amoo ${ }^{\mathrm{a}}$ ，汪婧奸 ${ }^{\mathrm{c}, \mathrm{d}}$ ，吕 鹏 ${ }^{\mathrm{a}}$ ，吕成学 ${ }^{\mathrm{a}}$, \\ 邢 闯 ${ }^{\mathrm{a}, *}$ ，孙 剑 ${ }^{\mathrm{b}, \#}$, 椿范立 ${ }^{\mathrm{d}}$

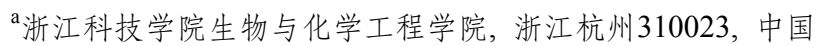 \\ ${ }^{\mathrm{b}}$ 中国科学院大连化学物理研究所洁净能源国家实验室(筹), 辽宁大连 116023 , 中国 \\ c 北京兴高化学技术有限公司, 北京100005, 中国 \\ d富山大学工学部, 富山9308555, 日本
}

摘要: 自2012年浙江大学肖丰收教授(J.Am. Chem. Soc., 2012, 134, 15173-15176)首次提出无溶剂法合成分子篮以来, 该路 线已备受关注. 无溶剂合成分子篎方法具有废液少、产率高、安全系数高等优点. 本文针对合成气经费托路线(FTS)一步 法制备富含异构烷烃汽油馏分的研究, 通过无溶剂研磨法制备了分子篮封装金属催化剂. 一般来说, 烷烃异构化催化剂的 
性能主要取决于分子篮的孔道结构及其酸性, 其次是分子篮晶粒大小、结晶度和表面性质等因素. 本文对比了三种具有相 同拓扑结构的MFI分子筛(Silicalite-1, HZSM-5和NaZSM-5)对汽油和异构烷烃选择性的影响规律. 结果显示, 在CO转化率 $(\sim 30 \%)$ 近似相同的情况下, 具有最弱酸性的Silicalite-1封装的Co颗粒表现出最高的汽油选择性( $~ 70 \%)$ 和异构烷烃选择性 ( $30.7 \%)$. 这意味着正构烷烃异构化反应只需要弱酸即可实现, 较强的酸性则会使其发生过度裂解反应. Py-IR谱图显示, Silicalite-1在 $1445 \mathrm{~cm}^{-1}$ 附近的L酸是区别于NaZSM-5和HZSM-5的一个重要酸性位, 可作为FTS路线制备富含异构烷烃汽油 的一个关键参数. 另外, 与封装型 $(\mathrm{Co} @ M F I)$ 催化剂相比, 浸渍型催化剂 $(\mathrm{Co} / \mathrm{MFI})$ 的汽油选择性明显偏低, 可能与金属活性 位与分子篮酸性位之间的距离有直接关系. 因此, 无溶剂合成分子篮是一条具有前景和适宜放大的催化剂合成路线.

对于合成气经费托路线制取富含异构烷烃汽油反应, 正构烷烃在分子篮催化剂上的裂解和异构化之间的竞争反应是 核心问题. 未来有待突破的研究方向包括: (1)多支链异构烷烃的合成, 目前对于有效调控多支链烷烃的生成关注较少; (2) 反应路线的设计, 合成气经甲醇路线, 联合甲醇制汽油(MTG)反应获得异构烷烃; (3)裂解反应的抑制; (4)分子篮孔道/笼对 异构烷烃选择性的调控机制.

关键词: 无溶剂合成; 分子篮封装; 钴催化剂; 费托合成; 汽油; 异构烷烃

收稿日期: 2019-08-25. 接受日期: 2019-10-05. 出版日期: 2020-04-05.

*通讯联系人. 电话: (0571)85070387; 传真: (0571)85070370; 电子信箱: xing@zust.edu.cn

\#通讯联系人. 电话/传真: (0411)84379283; 电子信箱: sunj@dicp.ac.cn

基金来源：浙江省自然科学基金(LY19B060001); 省部共建煤炭高效利用与绿色化工国家重点实验室开放课题(2018-K25).

本文的电子版全文由Elsevier出版社在ScienceDirect上出版(http://www.sciencedirect.com/science/journal/18722067). 